\author{
Adam KURZAWA ${ }^{1}$ \\ Krzysztof NAPLOCHA ${ }^{2}$ \\ Jacek W. KACZMAR ${ }^{3}$
}

\title{
WŁAŚCIWOŚCI MATERIAŁÓW KOMPOZYTOWYCH NA OSNOWIE STOPU ALUMINIUM EN AW-2024 I MIEDZI
}

\begin{abstract}
W pracy zostały przedstawione wyniki badań wpływu umocnienia stopu EN AW-2024 cząstkami ceramicznymi $\alpha-\mathrm{Al}_{2} \mathrm{O}_{3}$ oraz miedzi włóknami Saffil na wybrane właściwości mechaniczne. Materiały kompozytowe zostały wytworzone odlewniczą metodą infiltracji pod ciśnieniem preform ceramicznych charakteryzujących się porowatością otwartą. Stabilność termiczną oraz odporność na deformacje preform $\mathrm{w}$ trakcie procesu infiltracji zapewniono przez zastosowanie do ich budowy spoiwa krzemionkowego i odpowiedniej obróbki termicznej. W pracy, opierając się na badaniach struktury i analizy powierzchni przełomów badanych po wytrzymałościowych próbach technologicznych, wykazano wpływ umocnienia na mechanikę tworzenia złomu. Przeprowadzone badania wytworzonych materiałów potwierdziły ponadto ich bardzo dobre właściwości mechaniczne oraz eksploatacyjne, takie jak twardość i odporność na ścieranie, co tworzy zakres ich potencjalnych zastosowań w budowie środków transportu naziemnego.
\end{abstract}

Słowa kluczowe: materiały kompozytowe, właściwości mechaniczne, infiltracja pod ciśnieniem

\section{Wprowadzenie}

Materiały kompozytowe wytwarzane metodą prasowania ze stanu ciekłego (ang. squeeze casting) charakteryzują się jednorodną drobnoziarnistą strukturą zapewniającą dobre właściwości mechaniczne i użytkowe [1-2]. Ważnym elementem $w$ procesie wytwarzania tych materiałów jest stabilna preforma ceramiczna, charakteryzująca się porowatością otwartą z włókien i cząstek ceramicznych, której technologię wytwarzania opracowano na Politechnice Wrocławskiej [3-4]. Warunki cieplne w czasie krzepnięcia metalu w obrębie porowatej preformy powodują tworzenie drobnoziarnistej struktury, natomiast polepszenie właściwości mechanicznych wybranych stopów Al można uzyskać przez odpowiednią

\footnotetext{
1 Autor do korespondencji/corresponding author: Adam Kurzawa, Politechnika Wrocławska, Smoluchowskiego 25, 50-372 Wrocław, tel.: 71 3204235, e-mail: adam.kurzawa@pwr.edu.pl

${ }^{2}$ Krzysztof Naplocha, Politechnika Wrocławska, e-mail: krzysztof.naplocha@pwr.edu.pl

3 Jacek W. Kaczmar, Politechnika Wrocławska, e-mail: jacek.kaczmar@pwr.edu.pl
} 
obróbkę cieplną. Wytworzony w ten sposób materiał kompozytowy może, ze względu na obecność ceramicznego umocnienia, zachowywać się inaczej podczas obróbki cieplnej w porównaniu ze stopami Al niezawierającymi ceramicznego umocnienia. W związku z tym w niniejszej pracy opisano wpływ obróbki cieplnej na twardość oraz wytrzymałość na rozciąganie materiałów kompozytowych na osnowie powszechnie stosowanego w wytwarzaniu konstrukcji lekkich stopu EN AW-2024, umocnionego cząstkami ceramicznymi $\mathrm{Al}_{2} \mathrm{O}_{3}$. Zastosowane parametry obróbki T6 znacząco wpływają na kształtowanie właściwości zarówno czystej osnowy [5], jak i materiałów umocnionych cząstkami, a przeprowadzone badania potwierdziły duży wzrost twardości i wytrzymałości na rozciąganie po zastosowanej obróbce cieplnej T6.

W pracy przedstawiono ponadto wpływ umocnienia włóknami Saffil czystej miedzi ETP na wytrzymałość na rozciąganie i ściskanie. Badane materiały kompozytowe na osnowie miedzi charakteryzują się jednorodną strukturą, z dobrym połączeniem na powierzchniach międzyfazowych osnowy z włóknami $\mathrm{Al}_{2} \mathrm{O}_{3}$. Zastosowane umocnienie włóknami i cząstkami ceramicznymi poprawia właściwości wytrzymałościowe w szerokim zakresie temperatur przy zachowaniu dobrego przewodnictwa cieplnego i elektrycznego [6-11].

\section{Materiały kompozytowe na osnowie stopów Al}

Materiały kompozytowe na osnowie stopu EN AW-2024 wytworzono, opierając się na technice „squeeze casting”, stosując prasowanie ze stanu ciekłego z ciśnieniem infiltracji $100 \mathrm{MPa}$ oraz preformy ceramiczne o porowatościach 90, 80 i $70 \%$. Podgrzewanie preform do temperatury ok. $700^{\circ} \mathrm{C}$, tuż przed zalewaniem, pozwoliło zmniejszyć obciążenie próbki i uniknąć pękania włókien pod działaniem wysokiego ciśnienia. Przesycanie przeprowadzono w temperaturze $493^{\circ} \mathrm{C}$, a próbki chłodzono w wodzie o temperaturze $20^{\circ} \mathrm{C}$. Przeprowadzono badania wpływu czasu starzenia na twardość HBW. Badaniom zostały poddane próbki materiałów kompozytowych zawierających odpowiednio: 10, 20, 30\% obj. cząstek umacniających. W celach porównawczych badania zostały wykonane również na materiałach ze stopu referencyjnego niezawierającego umocnienia. Badania twardości przeprowadzono na twardościomierzu Brinella, stosując kulkę stalową o średnicy $2,5 \mathrm{~mm}$ oraz nacisk $\mathrm{P}=625 \mathrm{~N}$. Parametry starzenia powodujące maksymalny wzrost twardości ustalono na podstawie wystąpienia piku twardości (rys. 1.). Ostatecznie starzenie próbek przeprowadzono $\mathrm{w}$ temperaturze $120^{\circ} \mathrm{C}$ w czasie $10 \mathrm{~h}$. Nieumocniony stop EN AW-2024 po obróbce T6 charakteryzował się twardością rzędu $120 \mathrm{HBW}$. Wprowadzenie do stopu cząstek umacniających spowodowało zwiększenie twardości. Materiały z zawartością $20 \%$ obj. cząstek charakteryzowały się twardością $140 \mathrm{HBW}$, a materiały z zawartością $30 \%$ obj. cząstek miały twardość ok. $180 \mathrm{HBW}$, co oznacza ok. 50\% wzrost twardości w stosunku do nieumocnionej osnowy. 


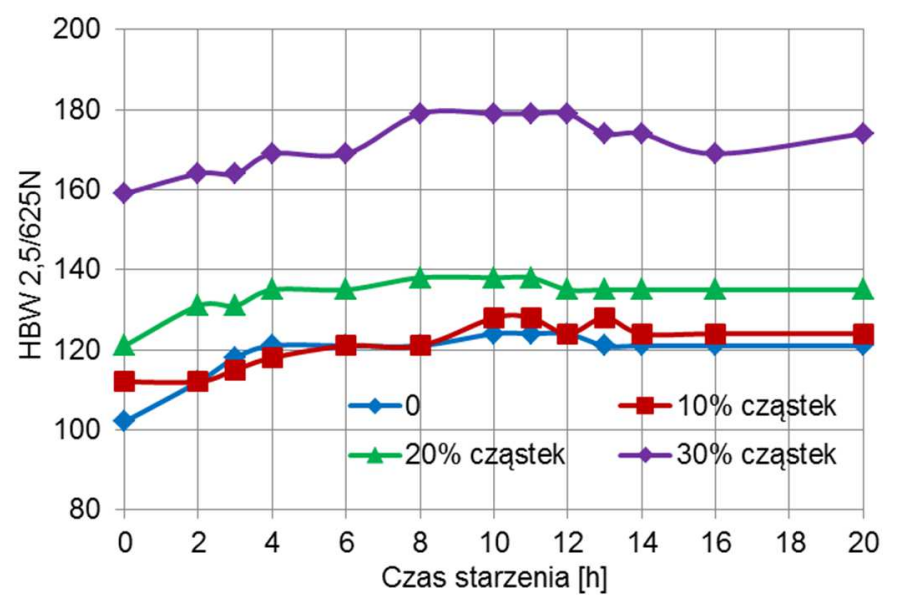

Rys. 1. Wpływ czasu starzenia na twardość HBW materiałów kompozytowych na osnowie stopów EN AW-2024 umocnionych cząstkami $\mathrm{Al}_{2} \mathrm{O}_{3}$

Fig. 1. The effect of ageing time on the HBW hardness of composite materials on the EN AW-2024 matrix strengthened with $\mathrm{Al}_{2} \mathrm{O}_{3}$ particles

Próbę rozciągania przeprowadzono, opierając się na normie PN-EN 10002-1:2004, na maszynie wytrzymałościowej firmy INSTRON 1126. Do badań użyto próbek o średnicy nominalnej $d=6,0 \mathrm{~mm}$ i długości części pomiarowej $l_{0}=30,0 \mathrm{~mm}$. W miarę zwiększania ilości fazy umacniającej obserwuje się stopniowy wzrost wytrzymałości zarówno próbek przed, jak i po obróbce cieplnej T6 (rys. 2.). Materiały kompozytowe nieobrobione cieplnie, zawierające $10 \%$ obj. cząstek ceramicznych charakteryzują się wytrzymałością $R_{m}$ wynoszącą ok. 160-170 MPa. Zwiększenie objętości cząstek do $30 \%$ obj. powoduje maksymalny wzrost wytrzymałości do wartości równej $350 \mathrm{MPa}$. Zastosowanie obróbki T6 powoduje wyraźny wzrost wytrzymałości na rozciąganie z 228 do $283 \mathrm{MPa}$ dla nieumocnionego stopu EN AW-2024. W materiałach kompozytowych z zawartością $10 \%$ obj. cząstek silny efekt umocnienia wydzieleniowego obróbki T6 osnowy przekłada się na wzrost wytrzymałości w stosunku podobnym jak w materiale nieumocnionym. Najniższy przyrost wytrzymałości po przeprowadzonej obróbce cieplnej, wynoszący zaledwie 3-6 MPa, stwierdzono w materiałach umocnionych $30 \%$ obj. cząstek $\mathrm{Al}_{2} \mathrm{O}_{3}$.

Obserwacje powierzchni przełomów próbek materiałów nieumocnionych uzyskanych w próbie rozciągania wykazały propagacje pęknięć głównie po granicach ziaren i ramionach dendrytów fazy $\alpha$, które ze względu na przetopienie stopów i odlanie do formy wykazują znaczne rozmiary w porównaniu z materiałem kształtowanym plastycznie. W obszarach międzydendrytycznych obserwacje potwierdziły występowanie nieznacznej porowatości. 


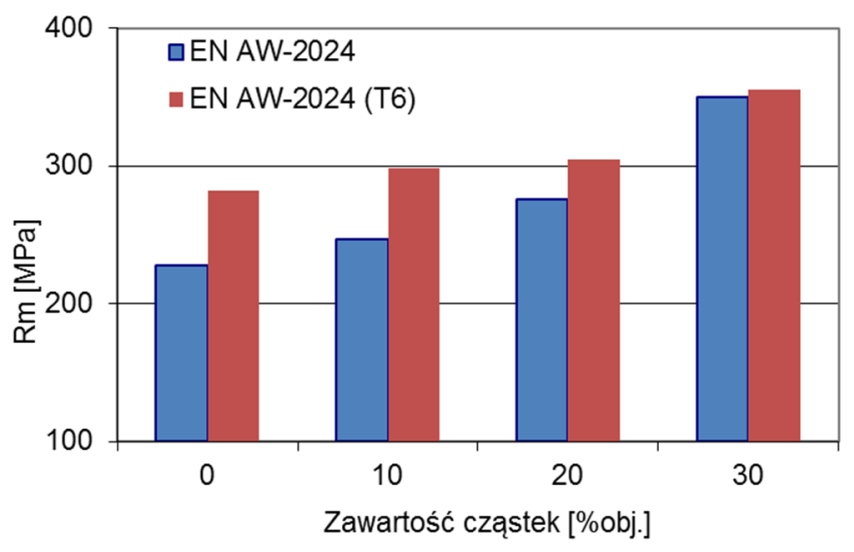

Rys. 2. Wytrzymałość na rozciąganie materiałów kompozytowych umocnionych cząstkami $\mathrm{Al}_{2} \mathrm{O}_{3}$ na osnowie stopów EN AW-2024 w stanie wytworzenia i po obróbce T6

Fig. 2. Tensile strength of composite materials strengthened with $\mathrm{Al}_{2} \mathrm{O}_{3}$ particles on the EN AW-2024 matrix after squeeze casting and the T6 heat treatment

W materiałach kompozytowych preforma składająca się ze sztywno połączonych spoiwem cząstek blokuje rozrost dendrytów fazy $\alpha$, w wyniku czego struktura jest bardziej drobnoziarnista. Na rysunku 3a pokazano SEM przełomu materiału kompozytowego AW-2024 - 10\% obj. cząstek $\mathrm{Al}_{2} \mathrm{O}_{3}$. Ze względu na obecność twardych cząstek przełomy materiałów kompozytowych mają zasadniczo charakter kruchy. Przy relatywnie małym udziale umocnienia w osnowie (np. $10 \%$ obj.) podczas rozciągania dochodzi do wyciągania niewielkich fragmentów osnowy z widocznymi nieznacznymi odkształceniami plastycznymi w kierunku działania siły rozciągającej. Cząstki umacniające skutecznie blokują odkształcanie plastyczne osnowy. Przeniesienie naprężeń z osnowy do cząstek ceramicznych w dużym stopniu zależy od jakości połączenia osnowy z umocnieniem na granicy międzyfazowej. W obserwowanych przełomach zauważa się odspajanie cząstek od osnowy, szczególnie w miejscach o słabym połączeniu osnowy z powierzchniami cząstek ceramicznych. W materiałach o większej objętości cząstek (rys. 3b) badania wykazały liczniejsze odspojenia.

W materiałach kompozytowych zawierających duże zawartości cząstek ceramicznych (30\% obj.) w wybranych miejscach obserwuje się lokalną porowatość szczątkową, będącą skutkiem niepełnej infiltracji. Dodatkowo pomiędzy aglomeratami cząstek stwierdzono zwiększoną zawartość $\mathrm{SiO}_{2}$ wykorzystywanego jako spoiwo do budowy preform. Istnienie obszarów o takiej strukturze zasadniczo ogranicza możliwości osnowy do przenoszenia naprężeń, co w konsekwencji powoduje osłabienie materiału. 
Rys. 3. Przełom materiału kompozytowego z osnową EN AW-2024: a) 10\% obj. cząstek $\mathrm{Al}_{2} \mathrm{O}_{3}$, b) $30 \%$ obj. cząstek $\mathrm{Al}_{2} \mathrm{O}_{3}$

Fig. 3. Fracture of composite materials based on the EN AW-2024 matrix: a) $10 \%$ vol. of $\mathrm{Al}_{2} \mathrm{O}_{3}$ particles, b) $30 \%$ vol. of $\mathrm{Al}_{2} \mathrm{O}_{3}$ particles
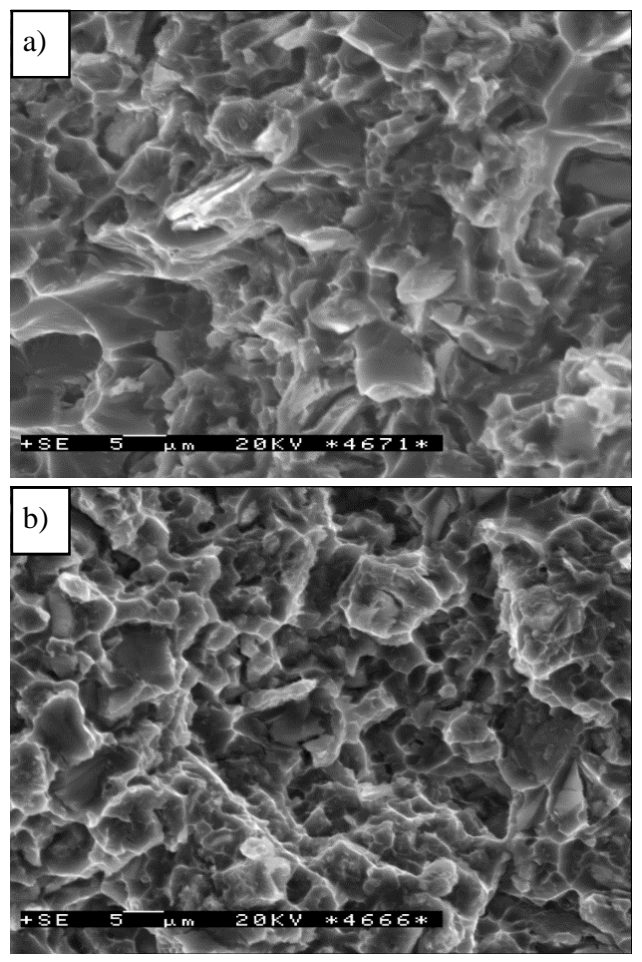

\section{Materiały kompozytowe na osnowie $\mathrm{Cu}$}

Dla materiałów kompozytowych i czystej miedzi wyznaczono umowną granicę plastyczności $\mathrm{R}_{0,2}$ na podstawie krzywych ściskania (rys. 4.). Niektóre próbki materiałów kompozytowych umocnionych $20 \%$ obj. włókien pękały z typową płaszczyzną poślizgu pod katem $45^{\circ}$. Jednak nawet $\mathrm{w}$ tym przypadku, po chwilowej utracie ciągłości, następowało sczepianie połówek pękniętej próbki i dalsze przenoszenie obciążenia. Umocnienie $\mathrm{Cu}$ włóknami $\mathrm{Al}_{2} \mathrm{O}_{3}$ powoduje znaczący wzrost umownej granicy plastyczności w całym badanym zakresie temperatur. Już $10 \%$ obj. włókien ceramicznych powoduje wzrost granicy o 50-80\%. Jednak materiały kompozytowe zawierające $20 \%$ tych włókien charakteryzowały się 2-3 razy większą wytrzymałością na ściskanie w porównaniu z nieumocnionymi próbkami z $\mathrm{Cu}$.

Zaobserwowano deformację mikrostruktury nieumocnionej $\mathrm{Cu}$ pod działaniem naprężeń ściskających wraz ze zniekształceniem ramion dendrytów. W kierunku prostopadłym do działania obciążenia i do osi próbki cylindrycznej ramiona dendrytów przemieszczały się, a rozmieszczona pomiędzy nimi eutektyka tlenkowa (w formie drobnych kulistych wydzieleń) również się przemieszczała i odkształcała. Umocnienie miedzi włóknami ceramicznymi powoduje rozdrobnienia zarówno struktury dendrytycznej, jak i eutektyki tlenkowej rozmieszczonej na 
granicach ziaren. Obciążone próbki przyjmowały kształt beczkowy, a powstające płaszczyzny poślizgu były trudne do zlokalizowania (rys. 5.). W ich obszarze dochodziło do znacznego pękania włókien i przemieszczania ich fragmentów pod kątem $45^{\circ}$ do osi próbki.

a)

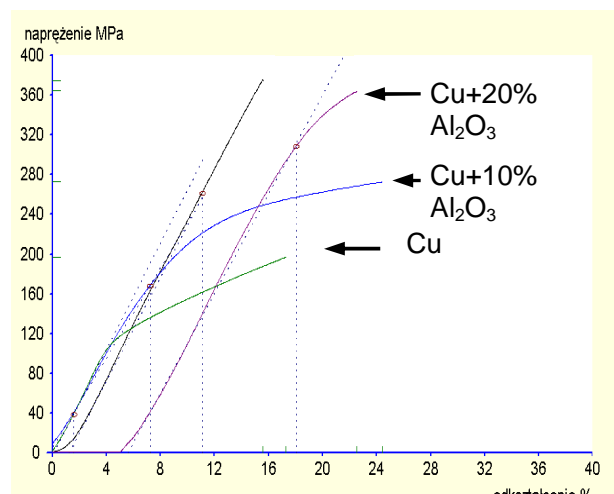

b)

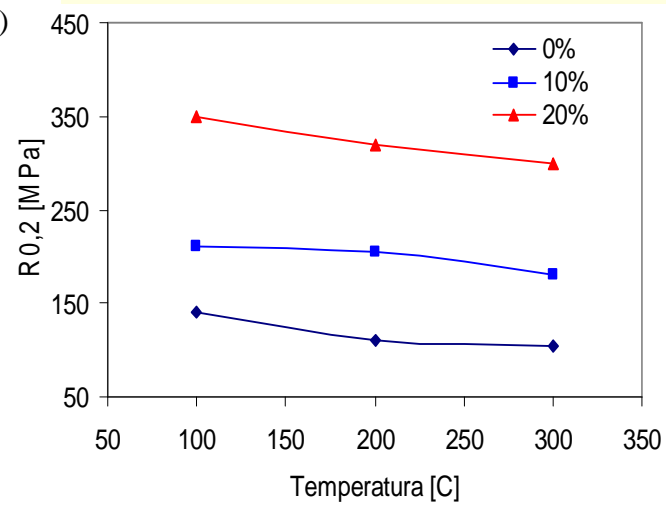

Rys. 4. Krzywe naprężenie-odkształcenie podczas ściskania w temperaturze $100^{\circ} \mathrm{C}$ (a) oraz umowna granica plastyczności $\mathrm{R}_{0,2}$ nieumocnionej $\mathrm{Cu}$ i materiałów kompozytowych umocnionych 10 i $20 \%$ obj. włókien w zakresie $100-300^{\circ} \mathrm{C}$ (b)

Fig. 4. Compression stress vs strain at $100^{\circ} \mathrm{C}$ (a) and the yield strength $\mathrm{R}_{0,2}$ of unreinforced $\mathrm{Cu}$ and composite materials reinforced with 10 and $20 \%$ vol. of fibers in the range of $100-300^{\circ} \mathrm{C}(\mathrm{b})$

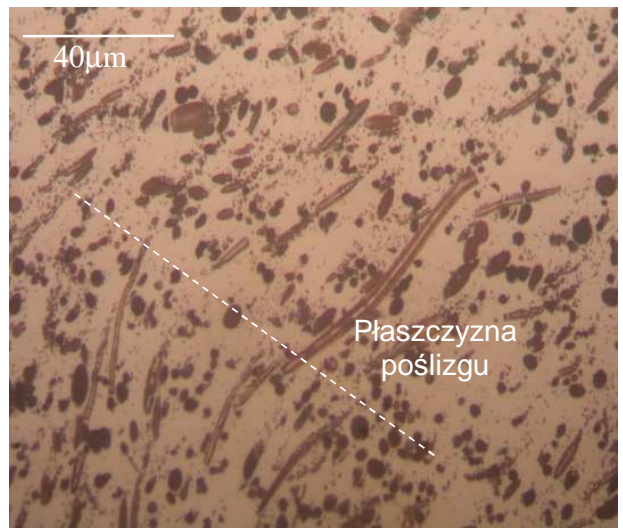

Rys. 5. Mikrostruktura materiału kompozytowego $\mathrm{Cu}-20 \%$ obj. włókien $\mathrm{Al}_{2} \mathrm{O}_{3}$ po ściskaniu $\mathrm{w} 100^{\circ} \mathrm{C}$ - zarys płaszczyzny poślizgu z zakrzywionymi i spękanymi włóknami

Fig. 5. Microstructure of the composite material $\mathrm{Cu}-20 \%$ vol. of $\mathrm{Al}_{2} \mathrm{O}_{3}$ fibers after compression at $100^{\circ} \mathrm{C}-$ outline of the slip plane with deformed and cracked fibers 
W całej objętości materiału włókna zostały poddane dużym naprężeniom i w zniekształconej osnowie pękają w zależności od kierunku ułożenia. W niższej temperaturze i przy mniejszej zawartości włókien ceramicznych $(10 \%$ obj.) można zauważyć ich segmentację, jeżeli są ustawione prostopadle do kierunku obciążenia, w bezpośrednim sąsiedztwie płaszczyzny poślizgu. Ułożone zgodnie $\mathrm{z}$ tym kierunkiem mogą pękać w sąsiedztwie charakterystycznej płaszczyzny poślizgu. Przy większej zawartości włókien takie zjawisko występuje tylko w wyższej temperaturze $-300^{\circ} \mathrm{C}$. Większa liczba włókien efektywniej przenosi obciążenie, odkształcenie plastyczne osnowy jest mniejsze, ściskanie materiału kończy się zwykle powstaniem płaszczyzny poślizgu.

W stosunku do nieumocnionego odlewu charakteryzującego się wytrzymałością ok. $140 \mathrm{MPa}$, wytrzymałość materiałów kompozytowych zwiększa się do ok. 190 i $230 \mathrm{MPa}$ odpowiednio dla 10 i $20 \%$ obj. włókien (rys. 6.). Powoduje to ok. 50-80\% wzrost wytrzymałości w stosunku do nieumocnionej $\mathrm{Cu}$.

Rys. 6. Wytrzymałość na rozciąganie Rm nieumocnionej miedzi oraz materiałów kompozytowych na osnowie umocnionych 10 i $20 \%$ obj. włókien ceramicznych

Fig. 6. Ultimate tensile strength UTS of unreinforced copper and of composite materials on copper matrix, reinforced with 10 and $20 \%$ vol. of ceramic fibers

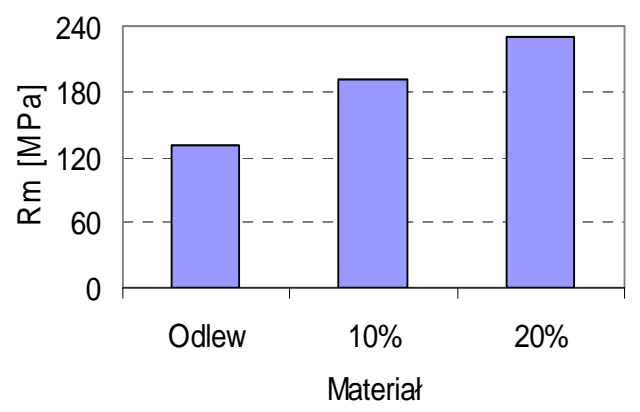

Włókna ceramiczne wiążą osnowę i zapobiegają jej pękaniu, natomiast pęknięcia w osnowie przebiegają głównie w obszarach międzydendrytycznych (rys. 7a). Występują tam kuliste tlenki $\mathrm{CuO}$, powstające przypuszczalnie podczas topienia i infiltracji prowadzonej bez osłony gazowej. O rozwoju przełomu kompozytu decyduje ukierunkowanie włókien i ich połączenie z osnową. Widoczne na przełomie ślady po wyłamanych włóknach czy też przytwierdzone fragmenty świadczą o dobrym połączeniu z osnową (rys. 7b). Nie zaobserwowano nadmiernego wyciągania włókien ,pull-out” i charakterystycznych dla tego zjawiska cylindrycznych zagłębień. Mniejsza (10\% obj.) zawartość włókien ceramicznych w osnowie nie pozwala na ograniczenie odkształceń sprężysto-plastycznych, co w efekcie prowadzi do pękania włókien na mniejsze segmenty i rozwoju przełomu. Z tego powodu w sąsiedztwie przełomu (rys. 8a) większość włókien była zniszczona. Obserwowano prostopadłe pęknięcia do osi włókien, szczególnie we włóknach ułożonych zgodnie z kierunkiem rozciągania.

Przy większej, 20\% obj., zawartości włókien ceramicznych w obszarach oddalonych od powierzchni przełomu nie obserwowano tak intensywnej fragmentacji włókien (rys. 8b). Jedynie tuż pod powierzchnią przełomu, na głębokości kilku mikrometrów, pęknięcia były wyraźne, choć również nie obserwowano wyciąga- 
nia ich fragmentów. Można stwierdzić, że kruchy przełom następował w miejscu występowania wad strukturalnych, np. przy porowatości czy pękach włókien.
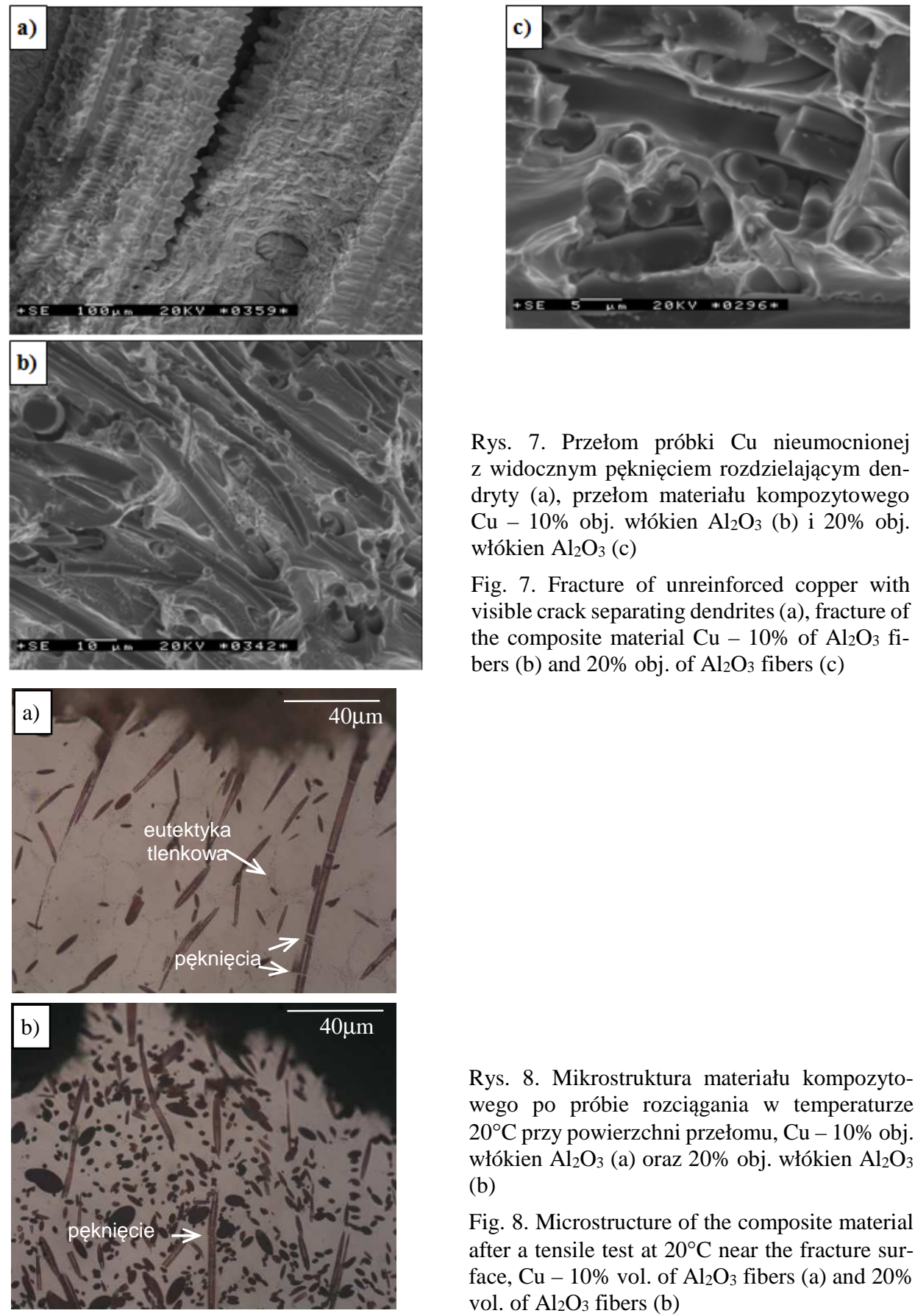

Rys. 7. Przełom próbki $\mathrm{Cu}$ nieumocnionej $\mathrm{z}$ widocznym pęknięciem rozdzielającym dendryty (a), przełom materiału kompozytowego $\mathrm{Cu}-10 \%$ obj. włókien $\mathrm{Al}_{2} \mathrm{O}_{3}$ (b) i $20 \%$ obj. włókien $\mathrm{Al}_{2} \mathrm{O}_{3}$ (c)

Fig. 7. Fracture of unreinforced copper with visible crack separating dendrites (a), fracture of the composite material $\mathrm{Cu}-10 \%$ of $\mathrm{Al}_{2} \mathrm{O}_{3}$ fibers (b) and $20 \%$ obj. of $\mathrm{Al}_{2} \mathrm{O}_{3}$ fibers (c)

Rys. 8. Mikrostruktura materiału kompozytowego po próbie rozciągania $\mathrm{w}$ temperaturze $20^{\circ} \mathrm{C}$ przy powierzchni przełomu, $\mathrm{Cu}-10 \% \mathrm{obj}$. włókien $\mathrm{Al}_{2} \mathrm{O}_{3}$ (a) oraz $20 \%$ obj. włókien $\mathrm{Al}_{2} \mathrm{O}_{3}$ (b)

Fig. 8. Microstructure of the composite material after a tensile test at $20^{\circ} \mathrm{C}$ near the fracture surface, $\mathrm{Cu}-10 \%$ vol. of $\mathrm{Al}_{2} \mathrm{O}_{3}$ fibers (a) and $20 \%$ vol. of $\mathrm{Al}_{2} \mathrm{O}_{3}$ fibers (b) 


\section{Wnioski}

1. Opierając się na metodzie prasowania ze stanu ciekłego przez infiltrację stopem EN AW-2024 porowatych preform ceramicznych wykonanych z proszku tlenku glinu $\mathrm{Al}_{2} \mathrm{O}_{3}$ charakteryzujących się porowatością otwartą, można wytwarzać materiały kompozytowe z równomiernym rozkładem cząstek ceramicznych w osnowie.

2. Obróbka cieplna T6 stosowana do utwardzania wydzieleniowego osnowy stopu EN AW-2024 materiałów kompozytowych umocnionych cząstkami powoduje znaczący wzrost twardości materiałów kompozytowych zawierających 10\% obj. i $20 \%$ obj. cząstek umacniających. Zastosowanie obróbki T6 materiałów kompozytowych zawierających $30 \%$ obj. cząstek nie spowodowało wyraźnego wzrostu twardości.

3. Umacnianie $\mathrm{Cu}$ włóknami ceramicznymi $\mathrm{Al}_{2} \mathrm{O}_{3}$ zwiększa znacząco właściwości wytrzymałościowe w szerokim zakresie temperatur. Wytrzymałość na ściskanie materiału kompozytowego zawierającego $20 \%$ obj. włókien SAFFIL w temperaturze $300^{\circ} \mathrm{C}$ wynosi $305 \mathrm{MPa}$. Obserwuje się ponadto zwiększenie wytrzymałości na rozciąganie. Kompozyt na osnowie miedzi umacniany $20 \%$ obj. włókien ceramicznych charakteryzuje się wytrzymałością na rozciąganie wynoszącą $220 \mathrm{MPa}$.

4. Analiza właściwości mechanicznych wytworzonych materiałów kompozytowych wskazuje na możliwość zastosowania materiałów kompozytowych na osnowie stopu EN AW-2024 na lekkie elementy w konstrukcjach naziemnych środków transportu, natomiast materiały kompozytowe na osnowie miedzi mogą być stosowane na wysokowytrzymałe elementy przewodzące prąd elektryczny oraz charakteryzujące się dobrym przewodnictwem cieplnym.

The results presented in this paper have been obtained within the project „KomCerMet” (contract no. POIG.01.03.01-00-013/08 with the Polish Ministry of Science and Higher Education, Warsaw) in the framework of the Innovative Economy Operational Programme (POIG) 2007-2014.

\section{Literatura}

[1] Hajjari E., Divandari M.: An investigation on the microstructure and tensile properties of direct squeeze cast and gravity die cast 2024 wrought Al alloy, Mater. Design, 29 (2008) 1685-1689.

[2] Fan C.H., Chen Z.H., He W.Q., Chen J.H., Chen D.: Effects of the casting temperature on microstructure and mechanical properties of the squeeze-cast $\mathrm{Al}-\mathrm{Zn}-\mathrm{Mg}-\mathrm{Cu}$ alloy, J. Alloys Compounds, 504 (2010) 42-45.

[3] Kaczmar J.W., Kurzawa A.: Structure and properties of porous ceramic preforms made of $\alpha$-alumina particles, Arch. Foundry Eng., 10 (2010) 157-162.

[4] Kaczmar J.W.: Wytwarzanie, własności i zastosowanie elementów z materiałów kompozytowych, Oficyna PWr, Wrocław 2013. 
[5] Regula T., Fajkiel A., Dudek P., Saja K.: Casting of wrought alloys under external pressure, Trans. Foundry Research Institute, 54 (2014) 3-11.

[6] Chen G.Q., Xiu Z.Y., Meng S.H., Wu G.H., Zhu D.Z.: Thermal expansion and mechanical properties of high reinforcement content $\mathrm{SiCp} / \mathrm{Cu}$ composites fabricated by squeeze casting technology, Trans. Nonferrous Metals Soc. China, 19 (2009) 600-604.

[7] Mahesh Kumar V., Venkatesh C.V.: Effect of ceramic reinforcement on mechanical properties of aluminum matrix composites produced by stir casting process, Mater. Today: Proceedings, 5 (2018) 2466-2473.

[8] Tian W.S., Zhao Q.L., Zhang Q.Q., Qiu F., Jiang Q.C.: Simultaneously increasing the high-temperature tensile strength and ductility of nano-sized $\mathrm{TiC}_{\mathrm{p}}$ reinforced Al-Cu matrix composites, Mater. Sci. Eng., A 717 (2018) 105111.

[9] Illgen A., Weidner A., Biermann H.: Influence of particle and short-fibre reinforcement on the very high cycle fatigue behaviour of aluminium matrix composites, International, J. Fatigue, 113 (2018) 299-310.

[10] Bai G., Li N., Wang X., Wang J., Kim M.J., Zhang H.: High thermal conductivity of $\mathrm{Cu}-\mathrm{B} /$ diamond composites prepared by gas pressure infiltration, J. Alloys Compounds, 735 (2018) 1648-1653.

[11] Wang W., Du A., Fan Y., Zhao X., Wang X., Ma R., Li Q.: Microstructure and tribological properties of $\mathrm{SiC}$ matrix composites infiltrated with an aluminium alloy, Tribology Int., 120 (2018) 369-375.

\title{
THE PROPERTIES OF THE EN AW-2024 ALUMINIUM ALLOY AND COPPER MATRIX COMPOSITE MATERIALS
}

\begin{abstract}
S u m m a r y
In this paper investigations of the strengthening effect of $\alpha-\mathrm{Al}_{2} \mathrm{O}_{3}$ particles and Saffil alumina fibres on the EN AW-2024 aluminium alloy matrix as well as $\mathrm{Cu}$ based composites on selected mechanical properties were presented. The examined composite materials were produced by pressure infiltration of open porosity preforms. Thermal stability and resistance to deformation of the preforms during the infiltration were provided by using a silica binder for reinforcing their structure and appropriate heat treatment. On the basis of microstructure and surface analysis of fractures obtained during strength investigations the effect of reinforcement and crack development were demonstrated. Performed tests of manufactured materials have also confirmed their superior mechanical and service properties, such as hardness and abrasion resistance, which widens the scope of their potential application.
\end{abstract}

Keywords: composite materials, mechanical properties, pressure infiltration

DOI: $10.7862 / \mathrm{rm} .2018 .28$

Otrzymano/received: 21.04 .2018

Zaakceptowano/accepted: 18.06.2018 